\title{
Bioactivity, physical and chemical properties of MTA mixed with propylene glycol
}

\author{
Vaishali Prakash NATU, Nileshkumar DUBEY, Gerald Choon Leong LOKE, Teng Seng TAN, Wee Hsuan NG, Chee \\ Weng YONG, Tong CAO, Vinicius ROSA
}

Faculty of Dentistry, National University of Singapore, Singapore.

Corresponding address: Vinicius Rosa - National University of Singapore, Faculty of Dentistry - 11 Lower Kent Ridge Road - Singapore - 119083 - Singapore - Phone: +65 67795555 ext 1650 - Fax: + 6567785742 - e-mail: denvr@nus.edu.sg

Submitted: March 18, 2015 - Modification: May 20, 2015 - Accepted: June 15, 2015

\section{ABSTRACT}

\begin{abstract}
bjective: To investigate the physical (setting time, hardness, flowability, microstructure) and chemical ( $\mathrm{pH}$ change, calcium release, crystallinity) properties and the biological outcomes (cell survival and differentiation) of mineral trioxide aggregate (MTA) mixed using different proportions of propylene glycol (PG) and water. Material and Methods: White MTA was mixed with different water/PG ratios (100/0, 80/20 and 50/50). Composition (XRD), microstructure (SEM), setting time (ASTM C266-13), flowability (ANSI/ADA 57-2000), Knoop hardness $(100 \mathrm{~g} / 10 \mathrm{~s}$ ) and chemical characteristics ( $\mathrm{pH}$ change and Ca2+ release for 7 days) were evaluated. Cell proliferation, osteo/odontoblastic gene expression and mineralization induced by MTA mixed with PG were evaluated. MTA discs ( $5 \mathrm{~mm}$ in diameter, $2 \mathrm{~mm}$ thick) were prepared and soaked in culture medium for 7 days. Next, the discs were removed and the medium used to culture dental pulp stem cells (DPSC) for 28 days. Cells survival was evaluated using MTS assay (24, 72 and $120 \mathrm{~h}$ ) and differentiation with RTPCR (ALP, OCN, Runx2, DSPP and MEPE) and alizarin red staining (7 and 14 days). Data were analysed using one-way ANOVA and Tukey's post-hoc analysis $(\alpha=0.05)$. Results: The addition of PG significantly increased setting time, flowability and $\mathrm{Ca}^{2+}$ release, but it compromised the hardness of the material. SEM showed that 50/50 group resulted porous material after setting due to the incomplete setting reaction, as shown by XRD analysis. The addition of PG (80/20 and 50/50) was not capable to improve cell proliferation or to enhance gene expression, and mineralized deposition of DPSC after 7 and 14 days as compared to the 100/0. Conclusion: Except for flowability, the addition of PG did not promote further improvements on the chemical and physical properties evaluated, and it was not capable of enhancing the bioactivity of the MTA.
\end{abstract}

Keywords: Dental pulp. Stem cells. Proliferation. Cell differentiation. Physical properties. Chemical properties. Hardness. Endodontics.

\section{INTRODUCTION}

Mineral trioxide aggregate (MTA) is a material with osteogenic, cementogenic and odontogenic potential that can be used for perforation repairs, pulp capping and pulpotomy ${ }^{17,29}$. It is also a retrograde root filling material frequently used in endodontic surgery procedures ${ }^{7}$. It has positive effects on proliferation of dental pulp stem cells (DPSC) in a dose-dependent manner ${ }^{11,27,28}$. The exposure of DPSC to MTA promotes upregulation of dentin sialophosphoprotein (DSPP), bone sialoprotein, increase in alkaline and phosphatase (ALP) activity.
It may also induce biomineralization ${ }^{11,16,18}$.

Water is normally used to mix MTA. It is necessary for the cement hydration reaction to release $\mathrm{Ca}^{2+}$ that ultimately stimulate differentiation of pulp cells ${ }^{13,26}$. However, this mix is difficult to manipulate, and the setting time of MTA is long ${ }^{4,21}$. Other vehicles have been proposed to alleviate these problems. Yet, the clinical effects are controversial. $\mathrm{NaOCl}$, a common irrigating solution in endodontics, may improve handling properties and the setting time, but it also compromises the compressive strength of the compound ${ }^{14}$.

Propylene glycol (PG) is a viscous, colourless 
and odourless FDA-approved compound with antibacterial properties 3,22 . PG can be added to the mixing of MTA to improve handling properties. This strategy may also result in higher push-out bond strength ${ }^{25}$, increase in its sealing ability ${ }^{5}$ and higher $\mathrm{pH}$ and $\mathrm{Ca}^{2+}$ dissociation during the initial post-mixing periods ${ }^{10,12}$.

Different ratios of $P G$ and water affect the physical and chemical properties of MTA, since crystal hydration is an important factor for the setting reaction of MTA $^{6}$. The addition of high ratios of PG ( $\geq 50 \%)$ to the mixture result in a setting time deemed too long to be clinically acceptable. This can translate into higher solubility and greater formation of pores, which compromises the mechanical strength of the material ${ }^{10}$. As the decrease in water content in the mixture changes physical and chemical characteristics of MTA, the question that arises is whether it could also affect its bioactivity. Thus, the aim of this study was to evaluate the effects of PG at different concentrations on physical and chemical properties, and the bioactivity of MTA.

\section{MATERIAL AND METHODS}

\section{MTA preparation}

$0.1 \mathrm{~g}$ of White MTA (ProRoot MTA, Dentsply, Tulsa, Oklahoma, USA) was mixed with $30 \mu$ lof the delivery vehicle prepared using different proportions of ultrapure water (UW) and PG (Table 1).

\section{$\mathrm{pH}$ and $\mathrm{Ca}^{2+}$ release}

Twenty-four polypropylene sterile micro pipette tips (length of $31.1 \mathrm{~mm}$, inner diameter: $3.35 \mathrm{~mm}$ top, $0.4 \mathrm{~mm}$ bottom) were immediately filled with MTA mixed with different proportions of UW and PG (Table 1) and allowed to set for 24 hours at $37^{\circ} \mathrm{C}$ (standard setting protocol used, except for hardness and flowability tests). Next, the micro pipette tips were placed independently in tubes containing $10 \mathrm{~mL}$ of UW. Half of the tubes were used to evaluate $\mathrm{pH}$ changes after 3, 24, 72 and 168 hours of incubation $(n=3)$. The remaining tubes were used to assess $\mathrm{Ca}^{2+}$ release at the same time points $(n=3)$ by inductively coupled plasma mass spectrometer (ICP-MS, Agilent 770, Santa Clara, California, USA). Briefly, $2 \mathrm{~mL}$ of the filtered UW with MTA was acidified with $2 \%$ of nitric acid. Fifty microliters of this solution were added to $4.95 \mathrm{ml}$ of UW in an ICP-MS vial (Autosampler vial, Nanonex Technology, Singapore) after calibration with standard solutions. UW alone was used as control agent in both tests.

\section{Setting time, flowability and hardness}

Setting time $(n=5)$ was measured with an ASTM C266-13 standard test method ${ }^{2}$. MTA mix was inserted into moulds, and the initial setting time was evaluated using a Gillmore needle (113.4 g) every 60 seconds. Only the initial setting time was considered, since it governs the handling time available for the clinicians.

Flowability testing $(n=5)$ was performed as recommended by ANSI/ADA 57-2000 ${ }^{1}$. Mixed MTA $(0.2 \mathrm{~mL})$ was placed over flat glass slab immediately after spatulation. After 3 minutes from the time of spatulation, another glass slab was placed over the mixture. Additional weight (120 g) was placed on top of the overlying glass slab, and the set-up was kept in an incubator $\left(37^{\circ} \mathrm{C}\right.$ and $95 \%$ relative humidity) for 10 minutes. The set up was then carefully transferred onto a piece of graph paper and the additional weight was removed. The maximum and minimum diameter of the circular shape formed by the cement was measured $(\mathrm{mm})$. Samples with a difference in minimum and maximum diameter of more than $1 \mathrm{~mm}$ were rejected. The average value of the two diameters was recorded as the measurement of flowability for each sample.

For microhardness $(n=3)$, five indentations were made per specimen after setting using Knoop diamond indenter (FM-100, Futuretech, Kawasaki, Kanagawa Prefecture, Japan, load of $100 \mathrm{~g}$ and dwell time of 10 seconds) and Knoop hardness $(\mathrm{HK})$, calculated according to equation 1 where $\mathrm{C}_{\mathrm{p}}$ is the correction factor related to the shape of the indenter (0.070279), P is the test load (kgf) and L is the length of the longer diagonal $(\mu \mathrm{m})$.

$$
H K=\frac{P}{\left(C_{p} L^{2}\right)} \quad \text { Equation } 1
$$

Scanning electron microscopy (SEM) and X-ray diffraction (XRD)

After setting, the MTA disks (5 $\mathrm{mm}$ in diameter, $2 \mathrm{~mm}$ in thickness)_were fractured and the crosssections observed under SEM (Quanta 650 FEGSEM, FEI, Hillsboro, Oregon, USA). Crystalline phase analysis of the unhydrated MTA powder and set MTA was obtained using an X-ray diffractometer (D8 Advance Powder X-ray Diffractometer, Bruker AXS, Karlsruhe, Baden-Württemberg, Germany) with a Ni filter and CuKa radiation $\left(\lambda=1.5425 \mathrm{~A}^{\circ}\right)$ at $40 \mathrm{kV}$ and $40 \mathrm{~mA}$ (scan range: $10-80^{\circ}$, scanning rate of $0.02 \%$ second). Crystalline formations were identified using JCPDS (Joint Committee on Powder Diffraction Standards) data file. MTA powder was used as control.

\section{Stem cell culture and preparation of MTA conditioned media}

The use of human dental pulp stem cells in this study was approved by the Institutional Review Board/NUS (Approval Number: NUS 2094). DPSCs between passages 3 and 6 (Allcells, Alameda, California, USA) were used to evaluate the cytotoxic and bioactivity of the groups. Cells 
were cultured in DMEM [Dulbecco's Modified Eagle Medium (Invitrogen, Carlsbad, California, USA)] supplemented with $10 \%$ fetal bovine serum (Invitrogen) and $1 \%$ penicillin/streptomycin (Invitrogen) ${ }^{24}$. Cells were passaged (TrypLE Select, Invitrogen) at $60-70 \%$ of confluency.

To prepare the MTA conditioned media (extracts), molds ( $5 \mathrm{~mm}$ in diameter, $2 \mathrm{~mm}$ in thickness) were filled with MTA cement mixed with different ratios of UW and PG (Table 1) and allowed to set. The discs obtained were immersed separately in $10 \mathrm{ml}$ of the culture medium described above for 7 days. After this period, the disks were removed and the extract kept in $4^{\circ} \mathrm{C}$ for no longer than 2 weeks.

\section{Cell viability assay}

DPSCs $\left(5 \times 10^{3}\right)$ were seeded in 96 well plates and treated with culture media (control) or MTA extracts $(n=3)$. Cell viability was determined after 1,3 and 5 days by using MTS assay (CellTiter 96 Aqueous One Solution; Promega, Madison, Wisconsin, USA) in a plate reader (Infinite M200, Tecan, Mannedorf, Meilen, Switzerland) at $490 \mathrm{~nm}$.
Quantitative Real time polymerase chain reaction (qRT-PCR) and alizarin Red staining

Expression of osteo/odontoblastic-related genes was performed with qRT-PCR after exposing the DPSCs to the MTA extracts for 7 and 14 days (Figure 1). RNA extraction was carried out with the RNA extraction kit (PureLink ${ }^{\mathrm{TM}}$ RNA Mini Kit, LifeTech, Carlsbad, California. USA), followed by cDNA synthesis (iScript RT Supermix, Bio-Rad, Hercules, California, USA) and PCR (Biorad-CFX Connect $^{\mathrm{TM}}$ Real time system, Hercules, California, USA). The primer sequences are listed in Figure 1. DPSC in culture medium alone served as control. Alizarin red staining (ARS) was performed to detect mineralization after 14 days. The cells were washed with PBS and fixed for 30 minutes. Alizarin red solution (Sigma-Aldrich, Saint Louis, Missouri, USA) was added and incubated for 30 minutes at $37^{\circ} \mathrm{C}$. Ten percent of cetylpyridinium chloride solution (Sigma-Aldrich) was added to each well, and the optical density was measured by a plate reader (wavelength $540 \mathrm{~nm}$ ). The culture medium was the negative control, and the osteogenic induction medium was included as a positive control. Tests were performed in triplicates.

Table 1- UW/PG ratio per $30 \mu \mathrm{l}$, setting time, flowability, Knoop hardness and ARS for the groups tested (different letters indicate statistically significant difference in columns) $(p<0.05)$

\begin{tabular}{ccccccc}
\hline Group & UW & PG & $\begin{array}{c}\text { Setting time } \\
(\mathbf{m i n})\end{array}$ & $\begin{array}{c}\text { Flowability } \\
\left(\mathbf{m m}^{\mathbf{2}}\right)\end{array}$ & Hardness (KH) & $\begin{array}{c}\text { ARS (relative } \\
\text { absorbance } \times 10-1)\end{array}$ \\
\hline $100 / 0$ & 30 & 0 & $18.3 \pm 0.3^{\mathrm{c}}$ & $11.5 \pm 0.2^{\mathrm{c}}$ & $5.8 \pm 0.1^{\mathrm{a}}$ & $6.9 \pm 1.2^{\mathrm{a}}$ \\
$80 / 20$ & 24 & 6 & $55.9 \pm 0.7^{\mathrm{b}}$ & $22.2 \pm 1.0^{\mathrm{b}}$ & $5.3 \pm 0.1^{\mathrm{b}}$ & $5.7 \pm 0.3^{\mathrm{a}}$ \\
$50 / 50$ & 15 & 15 & $191.0 \pm 0.5^{\mathrm{a}}$ & $30.2 \pm 2.1^{\mathrm{a}}$ & $3.4 \pm 0.1^{\mathrm{c}}$ & $6.4 \pm 0.5^{\mathrm{a}}$ \\
\hline
\end{tabular}

\begin{tabular}{|l|l|}
\hline Gene & Primer Sequence \\
\hline Alkaline phosphatase (ALP) & Forward: 5'-AAGTACTGGACAGACCAAGC-3' \\
\hline Osteocalcin (OCN) & Reverse: 5'-AGAGGGCCAAGAAGGGGAACT-3' \\
\hline Runt-related transcription factor 2 (Runx2) & Forward: 5'-ATGAGAGCCCTCAGACTCCTC-3' \\
\hline & Reverse: 5'-CGGGCCGTAGAAGCGCCGATA-3' \\
\hline Dentin sialophosphoprotein (DSPP) & Forward: 5'-CACTGGCGCTGCAACAAGA-3' \\
\hline & Reverse: 5'-CATTCCGGAGCTCAGCAGAATAA-3' \\
\hline Matrix extracellular phosphoglycoprotein (MEPE) & Forward: 5'-TGGCGATGCAGGTCACAAT-3' \\
\hline & Reverse: 5'-CCATTCCCACTAGGACTCCCA-3' \\
\hline b-Actin & Forward: 5'-GGCCAGTGACTGCGATTAAAC-3' \\
\hline & Reverse: 5'-CCTTCGAGTGTGCTTTAGCAT-3' \\
\hline
\end{tabular}

Figure 1- Primer sequences 


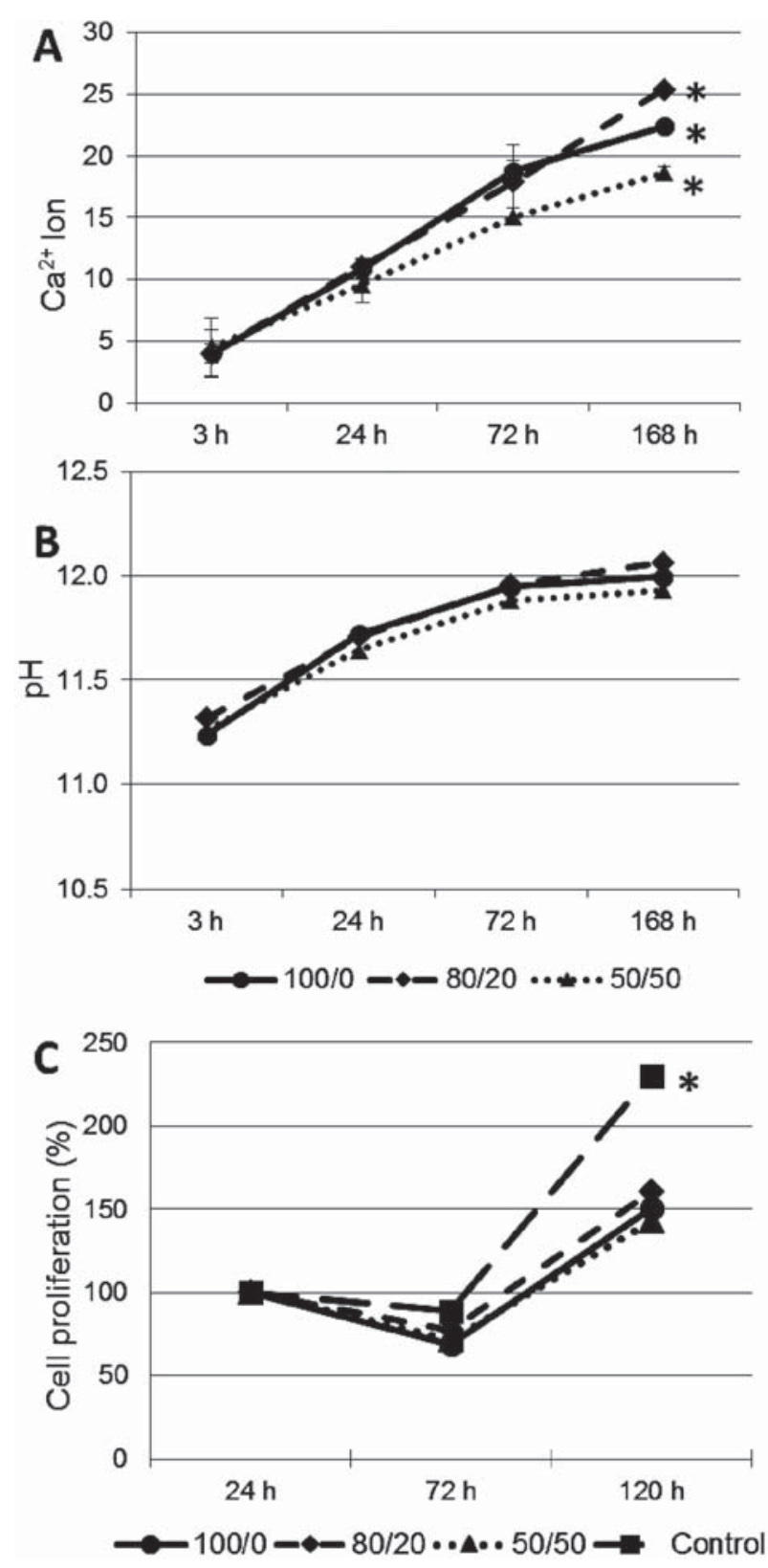

Figure 2- $\mathrm{Ca}^{+}$release $(\mathrm{A}), \mathrm{pH}$ variation $(\mathrm{B})$ and cell proliferation $(\mathrm{C})$ at different time points. *denotes statistical difference for that time point $(p<0.05)$

\section{Statistical analyses}

Statistical analyses were performed with either the one-way analysis of variance (ANOVA) and Tukey's post-hoc analysis $(\alpha=0.05$, SPSS V.22, IBM, USA).

\section{RESULTS}

Figure 2 shows the $\mathrm{Ca}^{2+}$ release $(A)$ and $\mathrm{pH}$ changes (B). After 168 hours, the amount of $\mathrm{Ca}^{2+}$ was significantly different for the three groups, with the highest amount for $80 / 20$. There was no significant increase in the $\mathrm{pH}$ for all the groups at all times. After 72 hours, there was a significant decrease in cell viability for all groups, except for the control specimens (Figure 2C). A significant increase in cell proliferation was observed after 120 hours for all groups.

The shortest initial setting time, lowest flowability and highest hardness was observed for 100/0 compared to $80 / 20$ and $50 / 50$ groups (Table 1 ).

SEM (Figure 3 ) showed a smooth and compact surface for $100 / 0$. For $80 / 20$, needle-like structures were present on the crystals. For 50/50 these structures were more frequent, and voids were also present. The XRD (Figure 3 ) shows that for $100 / 0$ and $80 / 20$ there was a decline of intensities of tricalcium silicate $\left(\mathrm{Ca}_{3} \mathrm{SiO}_{5}, 2 \theta=29.7^{\circ}\right)$, dicalcium silicate $\left(\mathrm{Ca}_{2} \mathrm{SiO}_{4}, 2 \theta=32.1^{\circ}\right)$ and tricalcium aluminate $\left(\mathrm{Ca}_{3} \mathrm{Al}_{2} \mathrm{O}_{6}, 2 \theta=33.20^{\circ}\right)$ peaks compared to the MTA powder. The peaks for 50/50 group were almost similar to the XRD of powder.

Figure 4 shows the relative gene expression after 7 and 14 days upon the exposure to different MTA extracts. There was no significant difference for all genes tested after 7 days. In 14 days, OCN expression was significantly lower for 50/50 in comparison to $100 / 0$ and $80 / 20$ groups, but higher than the control. For Runx2, only the $100 / 0$ and $50 / 50$ were significantly higher than the control. DSPP and MEPE were significantly higher than the control only for $100 / 0$. The MTA extracts failed to induce calcium deposition after 14 days (Table 1 ) as relative absorbances were similar to the control (culture medium only).

\section{DISCUSSION}

Mixing MTA with water and PG at different concentrations resulted in a smooth mix. Yet the addition of PG reduces the amount of water available for the hydration reaction, resulting in longer initial setting times (Table 1 ). The adverse effects include longer waiting time to restore the tooth and higher solubility, which compromises the sealing ability of the material ${ }^{15,30}$. PG also increased flowability (Table 1 ). This could contribute to attain better adaptation to various irregularities present in the root canal system and improve the ability of the material to seep into perforations. Nevertheless, it may also provide greater difficulties to handle the material and insert the mix into the root canal in clinical practice.

Hardness can be used as an indicator of completeness of the setting reaction ${ }^{19}$. In our study, hardness significantly decreased with each increment of PG (Table 1). The higher hardness of $100 / 0$ may be attributed to a well hydrated and more compacted microstructure, as confirmed by XRD and SEM as observed in Figure 3.

Although the initial $\mathrm{Ca}^{2+}$ dissociation was not affected by the addition of PG, after 168 hours, the amount released for 80/20 was higher (Figure $2 \mathrm{~A}$ ). 

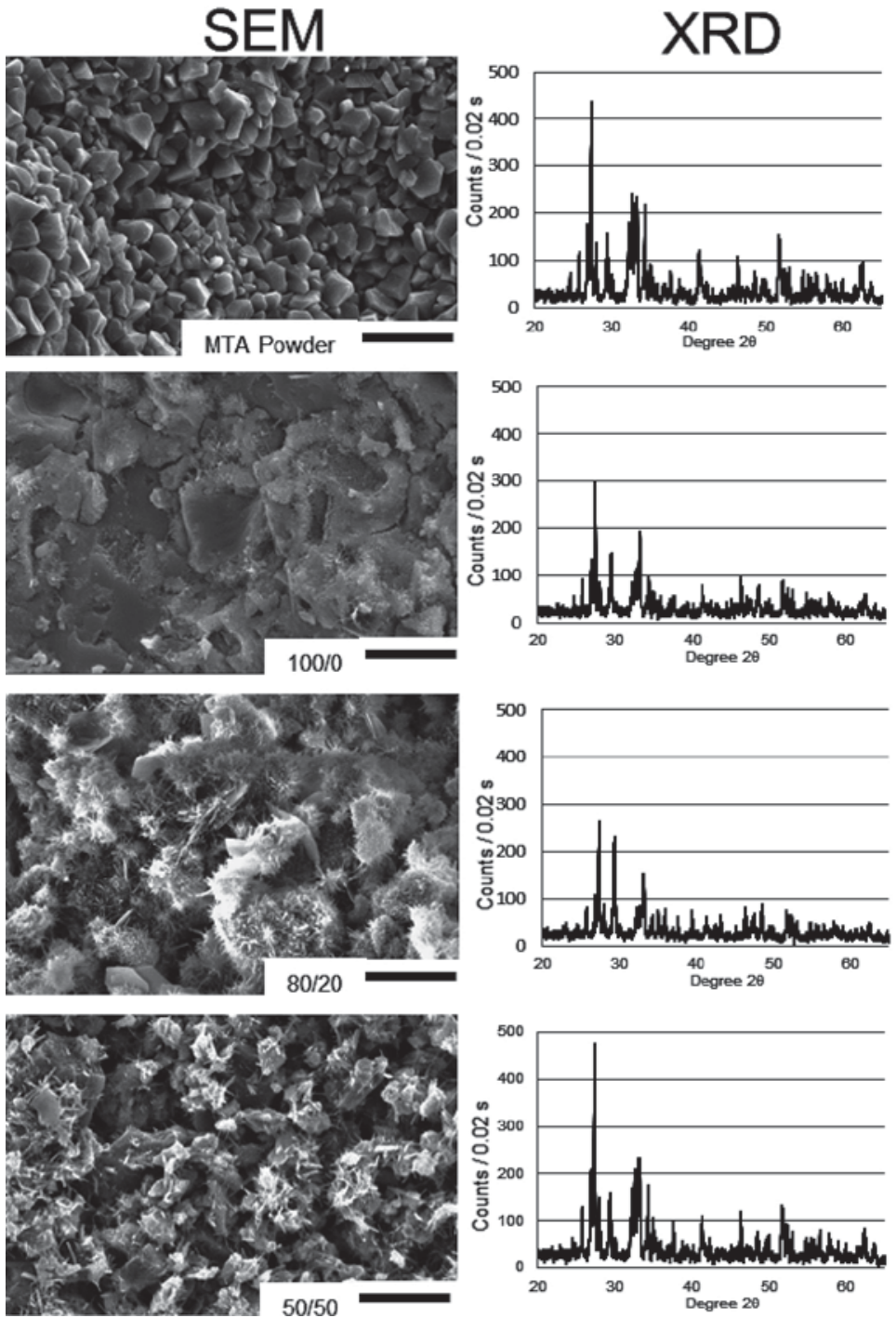

Figure 3- Scanning electron microscopy $(10,000 x)$ and XRD for all the groups tested and control (MTA powder)

MTA sets by a hydration reaction to form a calcium silicate hydrate gel (CSH) and calcium hydroxide $(\mathrm{CH}) . \mathrm{Ca}^{2+}$ is produced in high proportions from $\mathrm{CH}$ and by the decomposition of $\mathrm{CSH}$, which leads to an alkaline $\mathrm{pH}^{8}$. With a slower setting time, this process is probably sustained for a longer period. For 50/50, the available water will not be sufficient for the extensive hydration reaction, resulting in lower availability of $\mathrm{Ca}^{2+}$. In fact, as the hydration reaction of 50/50 is incomplete, conform indicated by the XRD analysis (Figure 3), there is no consumption of the peaks of interest compared to the set material (100/0).

Formation of calcified barriers may involve differentiation of stem cells into cells capable to form mineralized tissues ${ }^{23,24}$. Addition of PG did not alter the relative expression of genes investigated within the first seven days of evaluation. This lack of increased gene expression may be explained by the proliferation curve given in Figure $2 \mathrm{C}$, in which cell viability decreased by at least $30 \%$ for all experimental groups in the first three days. Similar trends were also observed by treating odontoblastlike MDPC-23 cells with the MTA extracts ${ }^{27}$. However, one study observed that MTA can increase proliferation of human dental pulp cells ${ }^{28}$. This controversial finding may be due to the different test settings that resulted in a lower $\mathrm{Ca}^{2+}$ concentration in the medium ${ }^{28}$. The decrease in $\mathrm{Ca}^{2+}$ induced cell death observed after 5 days, which could be related to the homeostatic mechanisms of cells to regulate their intracellular $\mathrm{Ca}^{2+}$ levels ${ }^{20}$. Hence, it is possible that cells need to recover from the initially harmful process caused by the high levels of $\mathrm{Ca}^{2+}$ before starting differentiation processes.

After 14 days, 100/0 showed a consistent increase in expression of all genes tested while the addition of $P G$ resulted in upregulation of the osteogenically related genes (ALP, OCN and Runx2). Although the amount of $\mathrm{Ca}^{2+}$ obtained for the 80/20 group was greater than $100 / 0$, this did not translate into an increased gene expression probably due to the similar $\mathrm{pH}$ observed in both (Figure 2B). Except for the Runx2, gene expression in the 50/50 

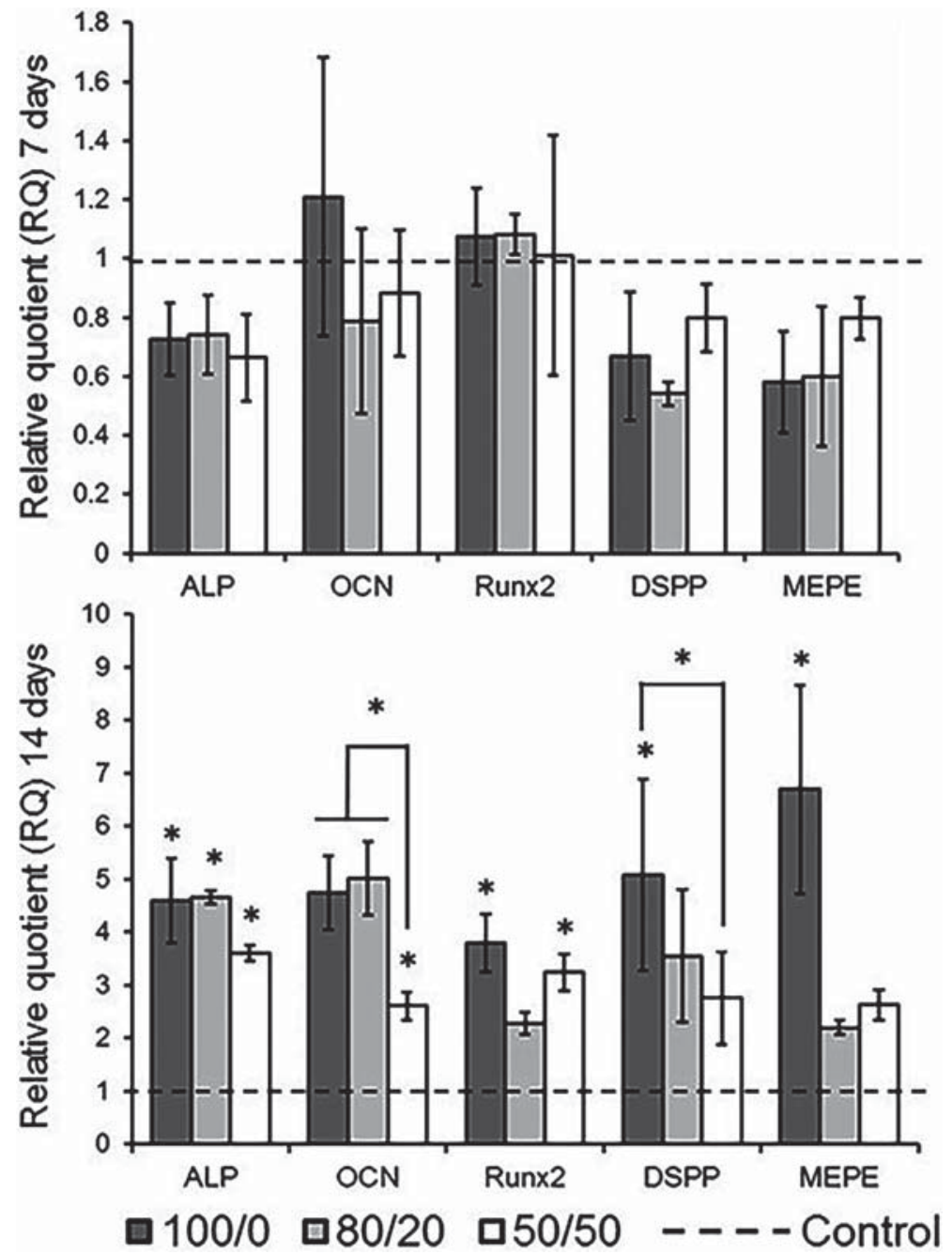

Figure 4- Genes expression after 7 (A) and 14 days (B) upon exposure to MTA extracts [ ${ }^{*}$ represents a significant difference $(p<0.05)$ between the group and the control. * above lines represents a significant difference between groups]

group was lower compared to that of the $100 / 0$ and $80 / 20$ groups. This can be credited to the lower $\mathrm{Ca}^{2+}$ release noted in the 50/50 group (Figure 2A). Hence, $\mathrm{Ca}^{2+}$ release and $\mathrm{pH}$ may act synergistically to induce cell differentiation. Despite the variation in gene expression, all the groups failed to induce mineralized matrix deposition (Table 1 ). This could be attributed to the short observation time of this study as DPSC are prone to differentiate towards a mineral-producing cell type ${ }^{9,23}$.

In summary, the addition of PG did not raise $\mathrm{pH}$ and calcium release over time, which resulted in deterioration of the cement's hardness and increase in setting time. On the other hand, the addition of $20 \%$ of PG to the mix of MTA increases $\mathrm{Ca}^{2+}$ release, but it is not able to modify the $\mathrm{pH}$ profile of the material. As this did not translate into higher differentiation of dental pulp stem cells in vitro, it is unlikely to have major biological effects in complex clinical situations. Nonetheless, this strategy improves handling properties and favors the flow of the material. Thus, clinicians must be aware that the use of PG to the mix may be considered to facilitate the penetration of MTA in curved root canals or to seal perforations, but the MTA bioactivity is not expected to be enhanced from the addition of this alternative vehicle.

\section{ACKNOWLEDGEMENTS}

The authors deny any conflicts of interest. This research was supported by grants from the National University of Singapore (R-221-000-061-133) and National Medical Research Council, Singapore (NMRC/CNIG/1107/2013). The authors want to thank Dr. Juan Alfredo Guevara Carrió (Universidade Presbiteriana Mackenzie) for the technical support provided for the XRD analysis.

\section{REFERENCES}

1- American Dental Association. ANSI/ADA Specification no 57: Endodontic sealing material. Chicago: ADA; 2000.

2- American Society for Testing and Materials. ASTM C266-13. Standard test method for time of setting of hydraulic-cement paste by Gillmore needles. West Conshohocken: ASTM; 2013. 
3- Ballal NV, Shavi GV, Kumar R, Kundabala M, Bhat KS. In vitro sustained release of calcium ions and ph maintenance from different vehicles containing calcium hydroxide. J Endod. 2010;36(5):862-6.

4- Ber BS, Hatton JF, Stewart GP. Chemical modification of proroot mta to improve handling characteristics and decrease setting time. J Endod. 2007;33(10):1231-4.

5- Brito-Júnior M, Viana FA, Pereira RD, Nobre SA, Soares JA, Camilo CC, et al. Sealing ability of mta-angelus with propyleneglycol in furcal perforations. Acta Odontol Latinoam. 2010;23(2):124-8

6- Camilleri J. Hydration mechanisms of mineral trioxide aggregate. Int Endod J. 2007;40(6):462-70.

7- Caron G, Azérad J, Faure MO, Machtou P, Boucher Y. Use of a new retrograde filling material (biodentine) for endodontic surgery: two case reports. Int J Oral Sci. 2014;6(4):250-3.

8- Darvell BW, Wu RC. "MTA" - an hydraulic silicate cement: review update and setting reaction. Dent Mater. 2011;27(5):407-22.

9- Davies OG, Cooper PR, Shelton RM, Smith AJ, Scheven BA. A comparison of the in vitro mineralisation and dentinogenic potential of mesenchymal stem cells derived from adipose tissue, bone marrow and dental pulp. J Bone Miner Metab. 2014. Epub ahead of print.

10- Duarte MA, Alves de Aguiar K, Zeferino MA, Vivan RR, OrdinolaZapata $\mathrm{R}$, Tanomaru-Filho $\mathrm{M}$, et al. Evaluation of the propylene glycol association on some physical and chemical properties of mineral trioxide aggregate. Int Endod J. 2012;45(6):565-70.

11- Hakki SS, Bozkurt SB, Hakki EE, Belli S. Effects of mineral trioxide aggregate on cell survival, gene expression associated with mineralized tissues, and biomineralization of cementoblasts. J Endod. 2009;35(4):513-9.

12- Holland R, Mazuqueli L, Souza V, Murata SS, Dezan Júnior E, Suzuki P. Influence of the type of vehicle and limit of obturation on apical and periapical tissue response in dogs' teeth after root canal filling with mineral trioxide aggregate. J Endod. 2007;33(6):693-7. 13- Holland R, Souza V, Nery MJ, Otoboni Filho JA, Bernabé PF, Dezan Júnior $E$. Reaction of rat connective tissue to implanted dentin tubes filled with mineral trioxide aggregate or calcium hydroxide. J Endod. 1999;25(3):161-6.

14- Kogan P, He J, Glickman GN, Watanabe I. The effects of various additives on setting properties of MTA. J Endod. 2006;32(6):56972.

15- Lee $\mathrm{YL}$, Lin $\mathrm{FH}$, Wang WH, Ritchie $\mathrm{HH}$, Lan WH, Lin CP. Effects of EDTA on the hydration mechanism of mineral trioxide aggregate. J Dent Res. 2007;86(6):534-8.

16- Maeda H, Nakano T, Tomokiyo A, Fujii S, Wada N, Monnouchi $S$, et al. Mineral trioxide aggregate induces bone morphogenetic protein-2 expression and calcification in human periodontal ligament cells. J Endod. 2010;36(4):647-52.
17- Main C, Mirzayan N, Shabahang S, Torabinejad M. Repair of root perforations using mineral trioxide aggregate: a long-term study. J Endod. 2004;30(2):80-3.

18- Min KS, Yang SH, Kim EC. The combined effect of mineral trioxide aggregate and enamel matrix derivative on odontoblastic differentiation in human dental pulp cells. J Endod. 2009;35(6):847-51

19-Nekoofar MH, Adusei G, Sheykhrezae MS, Hayes SJ, Bryant ST, Dummer PM. The effect of condensation pressure on selected physical properties of mineral trioxide aggregate. Int Endod J. 2007;40(6):453-61.

20- Nicotera P, Bellomo G, Orrenius S. Calcium-mediated mechanisms in chemically induced cell death. Annu Rev Pharmacol Toxicol. 1992;32:449-70.

21- Pelliccioni GA, Vellani CP, Gatto MR, Gandolfi MG, Marchetti C, Prati C. Proroot mineral trioxide aggregate cement used as a retrograde filling without addition of water: an in vitro evaluation of its microleakage. J Endod. 2007;33(9):1082-5.

22- Razmi H, Aminsobhani M, Bolhari B, Shamshirgar F, Shahsavan $S$, Shamshiri AR. Calcium enriched mixture and mineral trioxide aggregate activities against Enterococcus faecalis in presence of dentin. Iran Endod J. 2013;8(4):191-6.

23- Rosa V, Della Bona A, Cavalcanti BN, Nör JE. Tissue engineering: from research to dental clinics. Dent Mater. 2012;28(4):341-8.

24- Rosa V, Zhang Z, Grande RH, Nör JE. Dental pulp tissue engineering in full-length human root canals. J Dent Res. 2013;92(11):970-5.

25- Salem Milani A, Froughreyhani M, Charchi Aghdam S, Pournaghiazar F, Asghari Jafarabadi M. Mixing with propylene glycol enhances the bond strength of mineral trioxide aggregate to dentin. J Endod. 2013;39(11):1452-5.

26- Sarkar NK, Caicedo R, Ritwik P, Moiseyeva R, Kawashima I. Physicochemical basis of the biologic properties of mineral trioxide aggregate. J Endod. 2005;31(2):97-100.

27- Souza Costa CA, Duarte PT, Souza PP, Giro EM, Hebling J. Cytotoxic effects and pulpal response caused by a mineral trioxide aggregate formulation and calcium hydroxide. Am J Dent. $2008 ; 21(4): 255-61$

28- Takita T, Hayashi M, Takeichi O, Ogiso B, Suzuki N, Otsuka $\mathrm{K}$, et al. Effect of mineral trioxide aggregate on proliferation of cultured human dental pulp cells. Int Endod J. 2006;39(5):415-22. 29- Torabinejad M, Hong CU, Pitt Ford TR, Kaiyawasam SP. Tissue reaction to implanted super-EBA and mineral trioxide aggregate in the mandible of guinea pigs: a preliminary report. J Endod. 1995;21(11):569-71.

30- Vivan RR, Zapata RO, Zeferino MA, Bramante CM, Bernardineli N, Garcia RB, et al. Evaluation of the physical and chemical properties of two commercial and three experimental root-end filling materials. Oral Surg Oral Med Oral Pathol Oral Radiol Endod. 2010;110(2):250-6. 